\title{
Transient DNA damage following exposure to gold nanoparticles
}

\author{
Sarah May, ${ }^{a, b}$ Cordula Hirsch, ${ }^{a}$ Alexandra Rippl, ${ }^{a}$ Nils Bohmer, ${ }^{a}$ Jean-Pierre Kaiser, ${ }^{a}$ \\ Liliane Diener, ${ }^{a}$ Adrian Wichser, ${ }^{a}$ Alexander Bürkle ${ }^{b}$ and Peter Wick $(\mathbb{D}$ *a
}

Due to their interesting physicochemical properties, gold nanoparticles (Au-NPs) are the focus of increasing attention in the field of biomedicine and are under consideration for use in drug delivery and bioimaging, or as radiosensitizers and nano-based vaccines. Thorough evaluation of the genotoxic potential of Au-NPs is required, since damage to the genome can remain undetected in standard hazard assessments. Available genotoxicity data is either limited or contradictory. Here, we examined the influence of three surface modified 3-4 nm Au-NPs on human A549 cells, according to the reactive oxygen species (ROS) paradigm. After $24 \mathrm{~h}$ of Au-NP treatment, nanoparticles were taken up by cells as agglomerates; however, no influence on cell viability or inflammation was detected. No increase in ROS production was observed by $\mathrm{H}_{2}$-DCF assay; however, intracellular glutathione levels reduced over time, indicating oxidative stress. All three types of Au-NPs induced DNA damage, as detected by alkaline comet assay. The strongest genotoxic effect was observed for positively charged Au-NP I. Further analysis of Au-NP I by neutral comet assay, fluorimetric detection of alkaline DNA unwinding assay, and $\gamma \mathrm{H} 2 \mathrm{AX}$ staining, revealed that the induced DNA lesions were predominantly alkali-labile sites. As highly controlled repair mechanisms have evolved to remove a wide range of DNA lesions with great efficiency, it is important to focus on both acute cyto- and genotoxicity, alongside post-treatment effects and DNA repair. We demonstrate that Au-NP-induced DNA damage is largely repaired over time, indicating that the observed damage is of transient nature.

\section{Introduction}

Since gold in its bulk form has long been considered an inert material, gold nanoparticles (Au-NPs) were expected to behave similarly and to be non-cytotoxic. ${ }^{1,2}$ Due to their facile synthesis, with tunable sizes and shapes, and their unique physicochemical properties, such as chemical stability and excellent optical properties, Au-NPs are of great interest in various fields. In recent years, various applications for Au-NPs have emerged as potential players in the field of nanomedicine; for example, as sensitizers in radiation therapy, ${ }^{3}$ for bioimaging, ${ }^{4-6}$ for drug and gene delivery, ${ }^{7,8}$ as novel strategy

${ }^{a}$ Particles-Biology Interactions Laboratory, Swiss Federal Laboratories for Materials Science and Technology (Empa), Lerchenfeldstrasse 5, CH-9014 St. Gallen, Switzerland.E-mail: peter.wick@empa.ch

${ }^{b}$ University of Konstanz, Molecular Toxicology Group, Universitätsstrasse 10, D-78464 Konstanz, Germany for chemotherapy by conjugation to conventional drugs,,${ }^{9,10}$ or as nanoparticle-based vaccines. ${ }^{11,12}$

For the safe and efficient use of gold-based nanomedicines, assessment of their potential side effects is required as a sound basis for appropriate risk-benefit analyses. To date, there have been various reports, often with contradictory findings regarding the cyto- and genotoxicity of Au-NPs in vitro and in vivo; however, these are insufficient for comprehensive hazard assessment. While 1-2 nm Au-NPs exhibit high cytotoxicity, those of $15 \mathrm{~nm}$ are relatively non-toxic in various cell lines. ${ }^{13}$ Genotoxicity assessment of Au-NPs revealed a similar size-dependent effect in human bronchial epithelial cells, with $5 \mathrm{~nm}$ Au-NPs exhibiting genotoxicity, while those of $50 \mathrm{~nm}$ did not. ${ }^{14}$ Similarly, no genotoxicity was observed for 20 and $50 \mathrm{~nm}$ Au-NPs in HepG2 cells, whereas Au-NPs with a size of $5 \mathrm{~nm}$ induced DNA damage in a dose-dependent manner. ${ }^{15}$ These data indicate that very small Au-NPs, with a large surface to volume ratio, behave differently from their larger counterparts. One explanation for this phenomenon could be that Au-NPs below a certain size can cross phospholipid membranes, reach the nucleus, and bind to DNA, as reported by Tsoli et al., 2005. ${ }^{16}$ This could lead to direct induction of DNA damage by these small particles. 
Others showed that Au-NPs of $20 \mathrm{~nm}$ can induce oxidative DNA damage in lung fibroblasts and inhibit cell proliferation. ${ }^{17}$ Furthermore, human primary lymphocytes, as well as murine macrophages, exposed to citrate-capped 5 and $15 \mathrm{~nm}$ Au-NPs revealed oxidative DNA damage, chromosomal damage, and aneuploidogenic events; ${ }^{18}$ in this case the larger particles were more genotoxic than those that were smaller, indicating a different mode of action. Larger particles can most likely induce DNA damage indirectly, without entering the nucleus, as supported by various cell-based studies, the results of which suggest that Au-NPs can induce DNA damage via both their catalytic properties, ${ }^{19}$ and by interfering with the internal balance of reactive oxygen species (ROS) ${ }^{20,21}$ In rats, however, intratracheal instillation of uncoated 2, 20, and $200 \mathrm{~nm} \mathrm{Au-NPs}$ did not cause toxic effects in the lungs or other organs examined. Alkaline comet assay using lung tissue samples, and micronucleus assay on polychromatic erythrocytes of the bone marrow, demonstrated that none of these $\mathrm{Au}^{-}$ NPs were genotoxic in vivo. ${ }^{22}$ In contrast intraperitoneal injection of $1.9 \mathrm{~nm}$ Au-NPs was accompanied by an increase in 8-hydroxy-2'-deoxyguanosine levels, a marker for oxidative DNA damage, in rat brains. ${ }^{23}$ These data highlight the current dilemma in properly assessing the cyto- and genotoxicity of Au-NPs and demonstrate the uncertainties that remain a barrier to the comprehensive understanding of Au-NP-biointeractions, and impede efficient translation of this technology into the clinic.

The generation of ROS induced by engineered nanomaterials (ENM) is considered one potential cause of genotoxicity. ${ }^{24}$ ROS are generated during normal cellular metabolism and have important roles in cell signaling and homeostasis; ${ }^{25}$ however, due to the intrinsic properties of nanoparticles (e.g., high surface reactivity), these materials are able to disturb the natural and well-balanced occurrence of ROS in cells, either as direct response or through induction of inflammatory reactions, leading to subsequent increases in ROS generation. Induction of oxidative stress signaling cascades in response to nanoparticles has also been demonstrated. ${ }^{26-31}$ According to the so-called ROS paradigm, cells are able to tolerate ROS up to a certain level, as antioxidant enzymes and non-enzymatic ROS scavengers are able to neutralize excess ROS; ${ }^{32}$ however, if the production of ROS (regardless of its origin) exceeds the cell's natural antioxidant defense mechanisms, severe damage of cellular structures, such as membranes, proteins, lipids, and DNA, including oxidization of bases, single strand breaks, or double strand breaks, ${ }^{25}$ can result, and are cumulatively described as oxidative stress. The potential consequences of oxidative stress are inflammation, cytotoxicity, genotoxicity, and induction of apoptosis. ${ }^{33}$ Despite frequent exposure to stimuli with potential to damage DNA, cells can tolerate a certain degree of DNA damage, because of various DNA repair pathways that remove a wide variety of DNA lesions very efficiently (for a review see Dexheimer, 2013). ${ }^{34}$ Therefore, it is crucial to consider DNA repair in genotoxicity studies, and to discriminate between reversible and irreversible DNA damage.
To date, the majority of studies have focused only on the acute effects of Au-NPs, while long-term effects and post-treatment analysis, particularly considering DNA repair mechanisms, have largely been neglected. Therefore, we conducted a comprehensive and thorough in-depth study of both acute cytotoxicity according to the ROS paradigm (including ROS production, inflammation, oxidative stress, cell viability), and genotoxicity. Furthermore, we investigated the long-term effects following infliction of DNA-damage by a single exposure to positively charged Au-NPs, including DNA damage repair. To gain a fundamental understanding of basic nano-bio-interactions with focus on genotoxicity in response to Au-NPs three different particles with varying surface-modifications and charge were selected, as this can significantly affect the cellular response. ${ }^{35}$ These gold nanoparticle preparations (Au-NP I, II, and III) had a primary core size of 3-4 $\mathrm{nm}$ and served as models for our studies of A549 cells, a frequently used and well-known human lung-cancer alveolar epithelial cell line. Our results will shed light on the potential cytotoxic and genotoxic effects of Au-NPs, which will aid future research involving the development of Au-NPs for use in the biomedical field.

\section{Results and discussion}

\section{Physico-chemical characterization of Au-NPs}

Detailed material characterization of Au-NPs has been described by Bohmer et $a l^{36}$ Transmission electron microscopy (TEM) analysis was used to characterize the primary particle size and morphology of the three different Au-NPs. Analysis of TEM images revealed particles with a diameter of $3.1 \pm 1.3 \mathrm{~nm}$ for Au-NP I, $2.6 \pm 1.2 \mathrm{~nm}$ for Au-NP II and $2.2 \pm 0.8 \mathrm{~nm}$ for Au-NP III. Dynamic light scattering (DLS) analysis revealed hydrodynamic particle diameters ( $z$-average) of 147, 133, and $415 \mathrm{~nm}$ for Au-NP I, II, and III, respectively. Zeta potential measurements of the particles in water revealed values of $24.5,-48.1$, and $-49.5 \mathrm{mV}$ for Au-NP I, II, and III, respectively.

\section{Biological characterization of nanoparticle-cell interactions}

All three types of Au-NPs could be detected using light microscopy, despite their small primary size, as they formed agglomerates in cell culture media, which deposited on A549 cells within $24 \mathrm{~h}$ of incubation (Fig. 1a). While Au-NP I formed mainly spherical agglomerates of red and yellow color, various brown-colored structures, with a rather flaky appearance and varying sizes, were observed for Au-NP II; Au-NP III formed small agglomerates, similar to those observed for Au-NP I. Interestingly the number of agglomerates visible was the lowest for Au-NP III, indicating either the presence of other agglomerates, too small to be detected, or that fewer Au-NP III deposits formed on cells within $24 \mathrm{~h}$, compared with the other two particle types.

To demonstrate the uptake of Au-NPs in A549 cells, we used several different approaches. As side scatter (SS) values in flow cytometry indicate the granularity or complexity of cells, this 


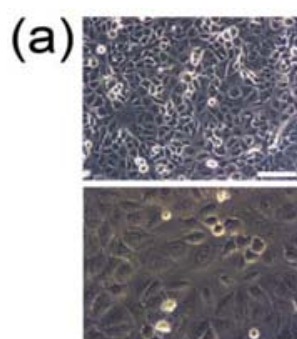

untreated

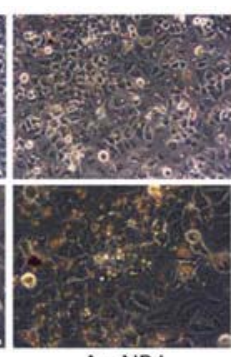

Au-NP I
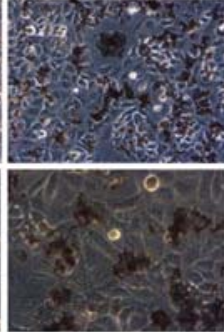

Au-NP ॥

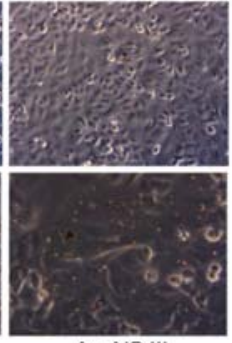

Au-NP III

(b)

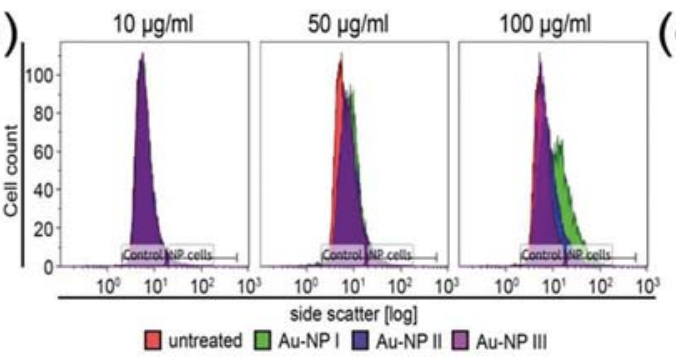

(c)

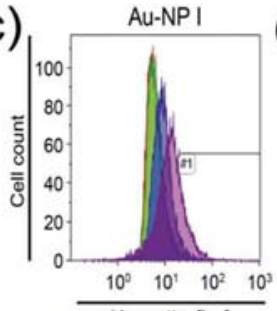

(d)

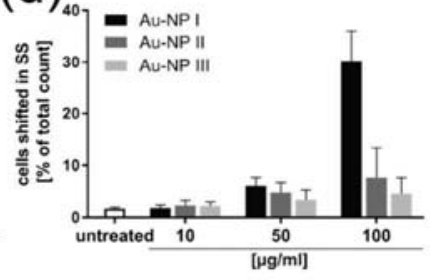

(e)
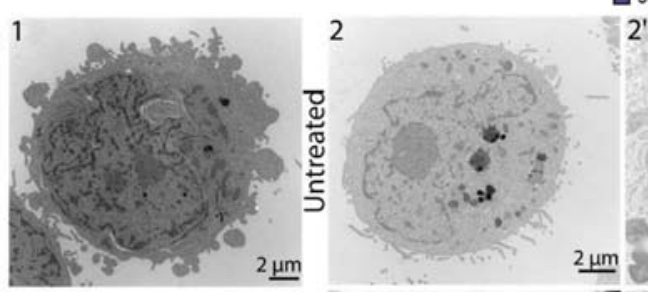

side scatter $[\mathrm{log}]$
untreated $\square$
$\square$

口 $50 \mu \mathrm{g} / \mathrm{ml} \square 100 \mu \mathrm{g} / \mathrm{ml}$

$2^{\prime}$

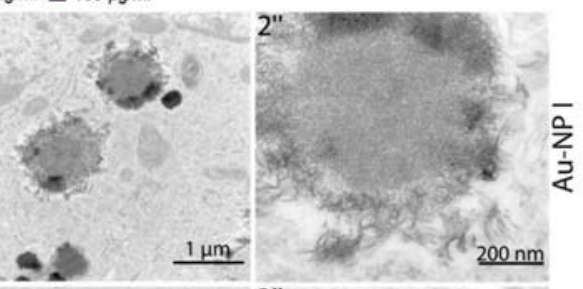

3 रो $3^{\prime}$ -

(f)

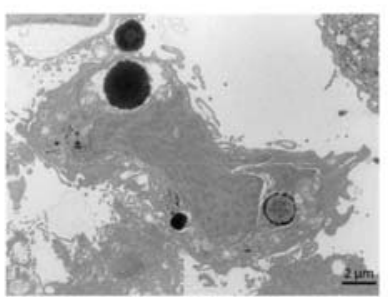

(g)
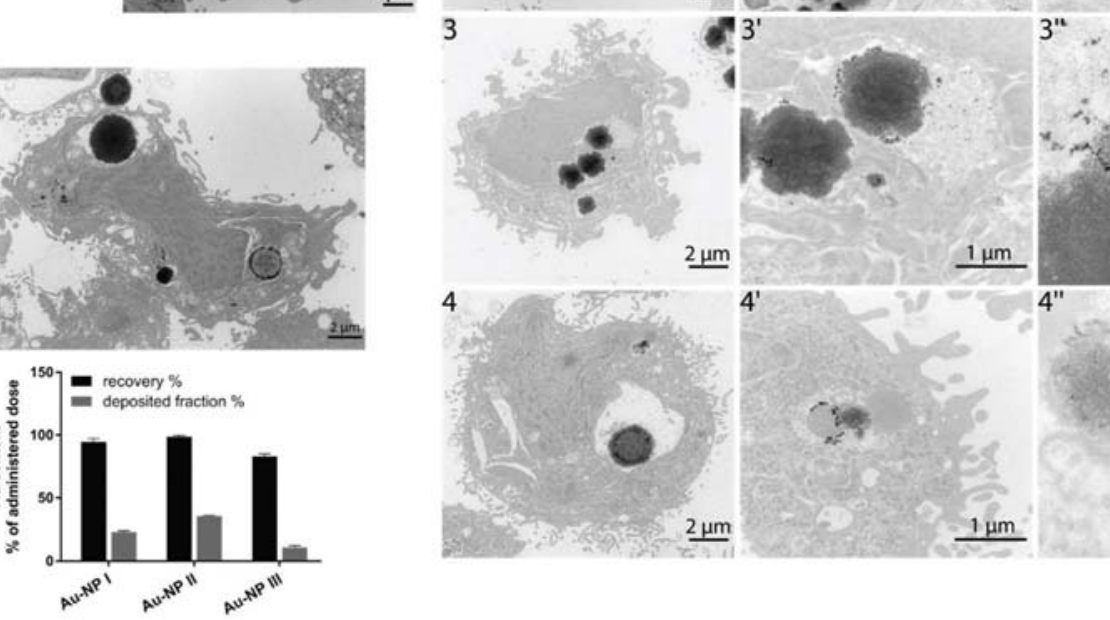

m
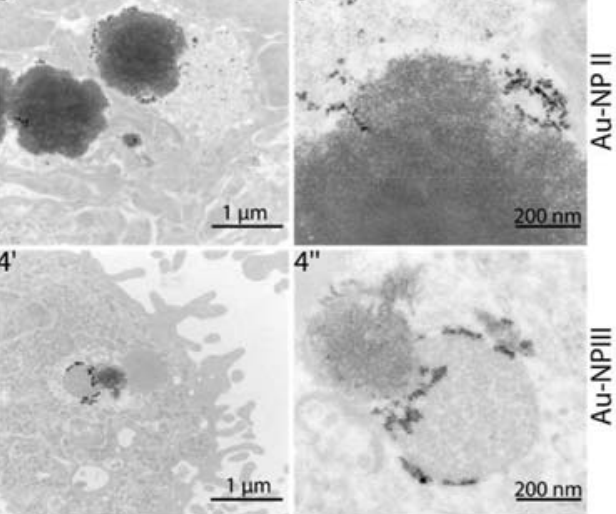

Fig. 1 Au-NP cell interaction and uptake. (a) Light microscopy images of untreated A549 cells and those treated with Au-NP I, II, and III. After $24 \mathrm{~h}$ incubation, agglomerates of Au-NPs were visible on the cell surfaces. Scale bar $100 \mu \mathrm{m}$ and $50 \mu \mathrm{m}$ for upper and lower panel, respectively. (b, c) Flow cytometric analysis of Au-NP adsorption/uptake to A549 cells after $24 \mathrm{~h}$ exposure. Side scatter (SS) values are plotted on a log scale. A total of 10000 counts were analysed per sample. (b) Histograms comparing the three different Au-NPs at various concentrations (indicated). (c) Dose-dependent increase in SS values for Au-NP I. (d) Quantitative analysis of cells shifted into gate \#1 after treatment with the three Au-NPs in four independent experiments. Mean values and corresponding standard deviations are shown. (e) TEM micrographs show the presence of all three types of Au-NP within A549 cells after $24 \mathrm{~h}$ exposure to $100 \mathrm{~g} \mathrm{ml}^{-1}$ Au-NP. Untreated A549 cells (1), cells treated with Au-NP I (2), Au-NP II (3), and Au-NP III (4). Representative TEM images (1, 2, 3, 4) and higher magnifications thereof $\left(2^{\prime}, 2^{\prime \prime} ; 3^{\prime}, 3^{\prime \prime} ; 4^{\prime}, 4^{\prime \prime}\right)$ are shown. (f) Variably structured agglomerates are visible, even within single cells, independent of the Au-NP type, as demonstrated by a representative image of Au-NP III. (g) ICP-OES data showing the percentages of recovered Au-NPs (I, II, III) and fractions deposited onto A549 cells after $24 \mathrm{~h}$. Mean values and corresponding standard deviations of three independent experiments are shown.

method can be used to demonstrate the uptake of nanoparticles. A dose-dependent shift (i.e., increase in SS values) was observed following incubation with titanium dioxide $\left(\mathrm{TiO}_{2}\right)$ nanoparticles; ${ }^{37}$ however, adsorption of NPs to the outside of the plasma membrane may result in a similar SS shift, hence uptake into the cell and adsorption to the cell surface cannot be distinguished. Fig. $1 \mathrm{~b}$ shows representative histograms of flow cytometry data from A549 cells treated for $24 \mathrm{~h}$ with three different concentrations $\left(10,50,100 \mu \mathrm{g} \mathrm{ml}^{-1}\right)$ of the three Au-NPs. Starting from $50 \mu \mathrm{g} \mathrm{m}{ }^{-1}$, an increase in 
granularity (SS values) is observed as a right shift of the blue and green curves for Au-NP II, with a more pronounced shift observed for Au-NP I. Fig. 1c shows the dose-dependent effect obtained for Au-NP I. The number of cells with increased granularity was quantified in gate \#1 (Fig. 1c), and served as a measure of Au-NP uptake/adsorption. Quantification data from four independent experiments is shown in Fig. 1d. Thirty per cent of cells showed increased granularity when treated for $24 \mathrm{~h}$ with $100 \mu \mathrm{g} \mathrm{ml} \mathrm{m}^{-1} \mathrm{Au}-\mathrm{NP}$ I. In contrast, only $7.7 \%$ and $4.6 \%$ of cells show a comparable shift in SS values when treated for $24 \mathrm{~h}$ with the same concentrations of Au-NP II and Au-NP III, respectively. Transmission electron microscopy (TEM) revealed that, after $24 \mathrm{~h}$, agglomerates of all three types of Au-NP were not only present on the cell surface, but had been taken up into cells to a certain extent (Fig. 1e), confirming the light microscopy observations of agglomeration formation outside cells, and demonstrating that Au-NP agglomerates are taken up by $\mathrm{A} 549$ cells, despite sizes up to the micro scale (Fig. 1e and f; ESI, Fig. S1†). Interestingly, the appearance of agglomerates was highly variable, even among the same type of Au-NP. Higher magnification images of these different structures are presented in Fig. 1e (2', 2"; 3', 3"; 4', 4"). There was no tendency of the three different Au-NPs to form a specific type of structure, rather they all adopted various shaped agglomerates, which were sometimes simultaneously detected within a single cell (Fig. 1f, magnifications thereof Fig. S2 $\dagger$ ). However, the presence and potential uptake of primary particles, in addition to the observed agglomerates, cannot be excluded based on these images. To further quantify the uptake of Au-NP $\left(100 \mu \mathrm{g} \mathrm{ml} \mathrm{m}^{-1}\right)$ in A549 cells, inductively coupled plasma optical emission spectroscopy (ICP-OES) measurements were performed after $24 \mathrm{~h}$ incubation. The recovery of the initially administered dose was very high for Au-NP I and II (94 and 99\% respectively), whereas the amount of recovered gold was somewhat lower for Au-NP III (83\%) (Fig. 1g). Calculations of the deposited fractions indicated that Au-NP I and II were associated with A549 cells (whether located on the cell surface and/or within the cells) to a similar extent (23\% and 36\%, respectively). For Au-NP III, a reduced amount (11\%) was deposited (Fig. 1g). Together, the data presented above clearly demonstrate that all three types of Au-NPs can deposit on cells and considerable proportions are taken up into A549 cells within $24 \mathrm{~h}$.

\section{Au-NP influence on cell viability}

The potential effect of Au-NP on A549 cell viability was assessed using the LDH assay, which detects lactate dehydrogenase $(\mathrm{LDH})$ release into the media from damaged cells, as a biomarker for cellular cytotoxicity and cytolysis. After 3 and $24 \mathrm{~h}$ of incubation, no increase in LDH release, was observed for any of the three Au-NPs applied (Fig. 2a and b). Cell free interference controls were performed independently (ESI, Fig. S4-S7†). No interference was observed using the LDH assay (for details see ESI $\dagger$ ). These results demonstrate that, despite their internalization, none of the Au-NPs caused acute cytotoxicity in A549 cells and are supported by the results of a separate study (Bohmer et al., submitted), which assessed A549 cell viability using the MTS assay following $24 \mathrm{~h}$ incubation with the same NPs. All concentrations of Au-NPs were in the sublethal range at all time points analysed. Thus, no DNA fragmentation due to cell death would be expected, allowing the investigation of genuine genotoxic events upon Au-NP treatment under the experimental conditions chosen.

\section{Investigation of Au-NP-induced ROS generation and inflammation}

According to the ROS paradigm, ENM-cell interactions, either through simple contact or ENM internalization, can result in overproduction of ROS and as a consequence in oxidative stress response, which is frequently observed and associated with NP toxicity. ${ }^{38,39}$ The catalytically active surface of ENM can generate increased ROS levels. ${ }^{33}$ Here, the ability of AuNPs to increase ROS production in A549 cells was assessed using the $\mathrm{H}_{2}$-DCF assay for up to $4 \mathrm{~h}$. Compared with untreated control samples, A549 cells treated with the positive control, Sin-1, exhibited an approximately 11-fold increase in ROS production (Fig. 3a). In contrast, none of the three Au-NPs caused elevation of ROS levels above those of untreated cells,
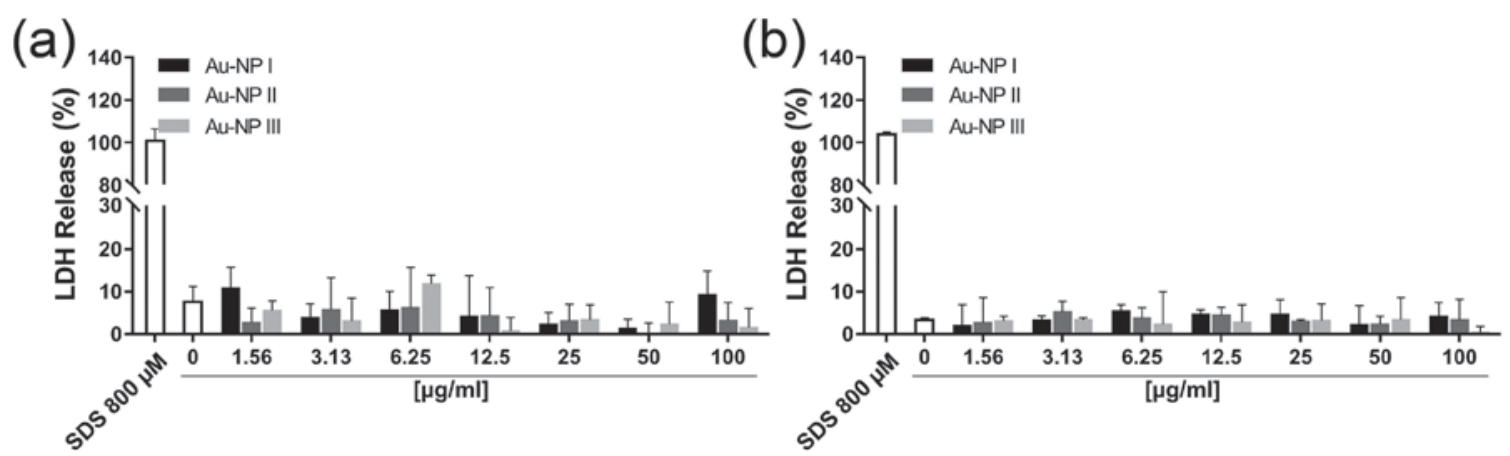

Fig. 2 Assessment of cell viability after exposure to Au-NPs. Following incubation of A549 cells with various concentrations of the different Au-NPs (I, II, III) for (a) $3 \mathrm{~h}$ and (b) $24 \mathrm{~h}$ cell viability was determined by measurement of LDH release in A549 cells. Incubation (24 h) with sodium dodecyl sulfate (SDS) served as the positive control. Mean values and corresponding standard deviations from three independent experiments with three technical replicates each are shown. 
(a)

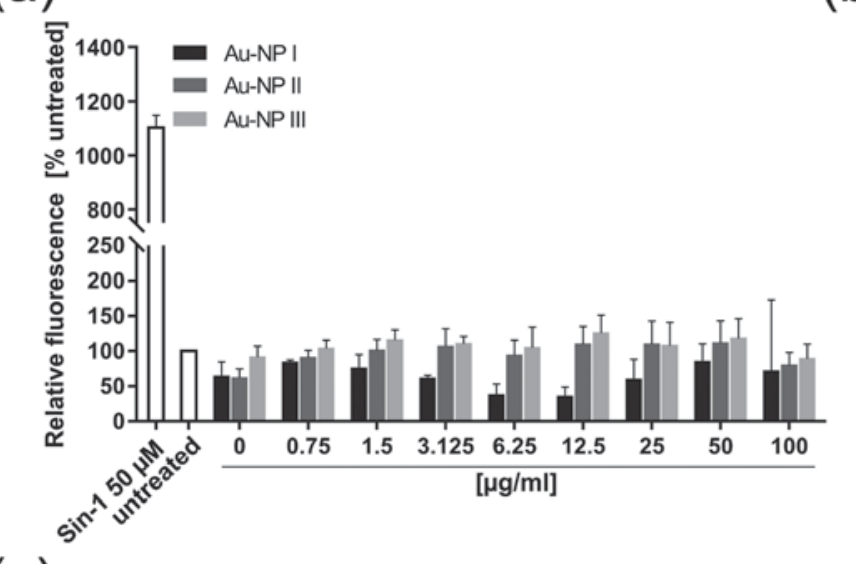

(b)

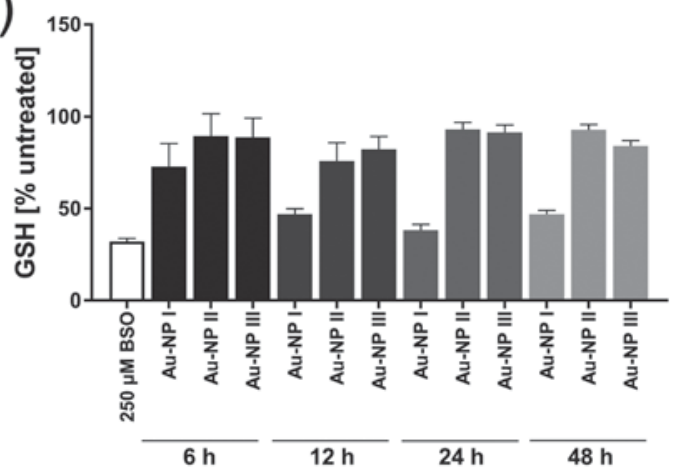

(c)

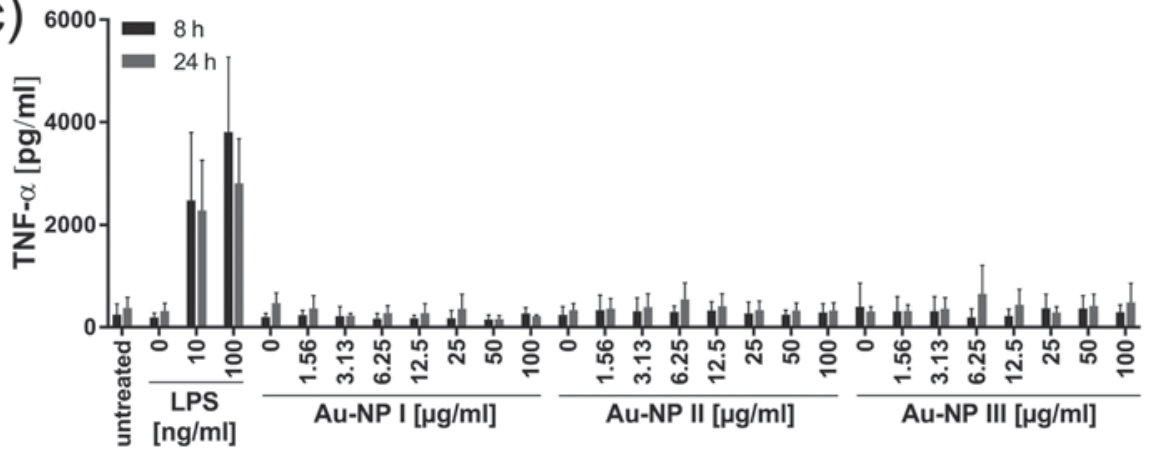

Fig. 3 Au-NP influence on ROS formation, oxidative stress, and inflammatory reactions. (a) ROS induction in A549 cells measured by $\mathrm{H}_{2}$-DCF assay after $3 \mathrm{~h}$ of exposure to Au-NPs (I, II, III). 3-Morpholinosydnonimine (Sin-1) served as chemical positive control. (b) Following exposure to $100 \mathrm{\mu g}$ $\mathrm{ml}^{-1} \mathrm{Au}-\mathrm{NP}$ (I, II, and III) for different incubation periods (6, 12, 24, and $48 \mathrm{~h}$ ), cellular glutathione (GSH) levels were determined. L-Buthionine-sulfoximine (BSO) treatment for $24 \mathrm{~h}$ served as a positive control. (c) Release of the pro-inflammatory cytokine, TNF- $\alpha$, from THP-1 derived macrophages following exposure to Au-NPs (I, II, and III) for 8 and $24 \mathrm{~h}$. LPS (10 and $100 \mathrm{ng} \mathrm{ml}^{-1}$ ) served as the positive control. Data represent the mean of three independent experiments and the corresponding standard deviation.

up to a concentration of $100 \mu \mathrm{g} \mathrm{ml} \mathrm{m}^{-1}$, with a $3 \mathrm{~h}$ incubation period (Fig. 3a). Auto-fluorescence of Au-NPs was not detected in cell free interference controls performed independently of the cell based $\mathrm{H}_{2}$-DCF-assay (ESI Fig. S8a†); however, all three $\mathrm{Au}-\mathrm{NPs}$ reduced the DCF signal in a dose-dependent manner, up to approximately $60 \%$ of the initial value (Fig. S8b $\dagger$ ), indicating possible quenching effects, and the potential for underestimation of cellular effects.

To address the possibility of false-positive results, we also investigated Au-NP reactivity towards $\mathrm{H}_{2}$-DCF in a cell free setup. Compared with Au-NP III and II, Au-NP I processed $\mathrm{H}_{2}$-DCF and increased fluorescence dose-dependently up to 6-fold at $100 \mu \mathrm{g} \mathrm{ml}{ }^{-1}$ (Fig. S8c $\dagger$ ). These data indicate that, at least for positively charged Au-NP, the ROS-inducing potential exceeds quenching properties and a cell reaction would be expected to be detectable. Since our results did not indicate measurable ROS overproduction in A549 and THP-1 cells (see ESI, Fig. S3 $\dagger$ ), a considerable influence of Au-NPs on cellular ROS levels under the experimental conditions chosen seems unlikely; however, the DCF-assay conditions differ from those of other cell-based assays included in this study, as Au-NPs were applied under serum-free conditions, and were, therefore, in a non-agglomerated state. This will alter, not only the dosimetry of Au-NPs, ${ }^{40}$ but also their interaction with cells, due to the lack of a protein corona. ${ }^{41-43}$ Furthermore, incubation times to assess the first burst release of ROS did not exceed $4 \mathrm{~h}$, thus Au-NP uptake may not have occurred within this time frame.

Also, considering the cell free controls, which indicated a certain reactivity of Au-NP I towards $\mathrm{H}_{2}$-DCF, cell reactions may have been overlooked for technical reasons. This demonstrates the importance of cell free interference controls for every assay, as well as the need for additional analyses to elucidate potential oxidative stress reactions upon Au-NP treatment.

To better understand cell reactions to Au-NPs in terms of ROS production and potential successive oxidative stress, we applied the glutathione (GSH) assay, an alternative method with a slightly different endpoint, but the same dosimetric settings as for all the other assays. This assay measures total cellular GSH, an important antioxidant that participates in the neutralization of ROS. Depletion of GSH is a biomarker for oxidative stress and was observed after exposure of A549 cells to Au-NPs at $100 \mu \mathrm{g} \mathrm{ml}^{-1}$ (Fig. 3b). Treatment with Au-NP I led to the strongest GSH depletion at each time point $(6,12,24$ and 
$48 \mathrm{~h}$ ). In addition, GSH depletion by Au-NP I increased with time and was most marked after $24 \mathrm{~h}$ of incubation. This phenomenon was less pronounced, or absent, using Au-NP II and III. These observations are in accordance with the ability of Au-NP I to oxidize $\mathrm{H}_{2}$-DCF in cell free experiments, and a further indication of the inability of the cellular $\mathrm{H}_{2}$-DCF-assay to detect this effect.

Cell free interference controls were performed separately and revealed negligible interference in the relevant concentration range (see ESI Fig. S9†). Based on these results oxidative stress in A549 cells appears to primarily be induced by positively charged Au-NP, hence this was investigated further.

One possible cell reaction to NP-induced oxidative stress is inflammation; therefore, the release of TNF- $\alpha$ in cell culture supernatants was determined following exposure of THP-1 derived macrophages to Au-NPs. The results revealed no changes in the level of released TNF- $\alpha$ after exposure to Au-NP for 8 or $24 \mathrm{~h}$, compared with untreated cells (Fig. 3c). Treatment with the positive control, lipopolysaccharide (LPS), induced release of up to $4500 \mathrm{pg} \mathrm{ml}{ }^{-1}$ TNF- $\alpha$. Therefore, inflammation does not appear to be an immediate response to Au-NP exposure.

\section{Assessment of the acute genotoxicity of Au-NPs}

Assessment of ENM-induced genotoxicity is of great interest, since DNA damage can lead to persistent mutations and/or genomic instability, and eventually result in uncontrolled cell proliferation (leading to cancer) or cell death. ${ }^{44}$ According to the ROS paradigm, genotoxicity can be induced in a ROSdependent or -independent manner. ${ }^{33}$ The most frequently used method for DNA damage detection, and also for evaluation of ENM-induced genotoxicity, is the alkaline version of the comet assay. ${ }^{45}$ Treatment of A549 cells with the three types of Au-NPs for $3 \mathrm{~h}$ did not induce DNA damage as measured by percentage tail intensity (Fig. 4a); however, after $24 \mathrm{~h}$ of incubation genotoxicity was observed for all three Au-NPs. The strongest effects, with tail intensities up to $60 \%$, were induced by 60 and $80 \mu \mathrm{g} \mathrm{ml} \mathrm{m}^{-1}$ of Au-NP I; however, genotoxic effects were already detected from $40 \mu \mathrm{g} \mathrm{ml}^{-1}$ (Fig. 4b). Au-NP II induced DNA damage to a lesser extent, also starting at 40 $\mu \mathrm{g} \mathrm{ml} \mathrm{m}^{-1}$, and reached a maximum tail intensity of $35 \%$ at 60 $\mu \mathrm{g} \mathrm{ml} \mathrm{m}^{-1}$. Interestingly, tail intensities declined at higher concentrations ( 80 and $100 \mu \mathrm{g} \mathrm{ml}^{-1}$ ) of Au-NP I and II. There are different possible reasons for this observation, including variation in concentration-dependent changes in the agglomeration state, dosimetry, or uptake behavior. The weakest DNA damaging effect was observed for Au-NP III, which induced tail intensities up to $20 \%$ at the highest concentration (100 $\mu \mathrm{g} \mathrm{ml} \mathrm{m}^{-1}$ ). These data demonstrate a clear ranking of the genotoxic potential of Au-NPs, with Au-NP I being the most genotoxic, followed by Au-NP II and III.

Importantly, our experiments measured true genotoxicity, since all administered concentrations were clearly sublethal, as previously demonstrated by MTS (Bohmer et al., submitted) and LDH release assays (Fig. 2). This is crucial, since DNA fragmentation, which occurs in the event of cell death, can lead to false positive results in the comet assay. As Au-NP I induced the most marked DNA damage, consistent with the results of GSH analysis and their potential to process $\mathrm{H}_{2}$-DCF in a cell free manner, further studies focused exclusively on this type of Au-NP. A time series on DNA damage induction following AuNP I exposure was conducted and a dose-dependent increase in DNA damage induction was observed over time $(3,6,9,12$, 24 h) (Fig. 4c). As samples were collected and frozen for each time point (see Materials and methods) and not directly processed, a slight overall increase in the tail intensity in all samples, including untreated control cells was observed. Nevertheless, DNA damage increased constantly, probably due to time-dependent deposition, interaction, and uptake of $\mathrm{Au}-$ NPs in A549 cells.

The fluorimetric detection of alkaline DNA unwinding (FADU) assay was performed as second independent method for genotoxicity assessment. In comparison to the results obtained by alkaline comet assay, exposure to Au-NP I for $24 \mathrm{~h}$ resulted in much lower levels of DNA damage (approximately 20\%) (Fig. 4d). This appears to be inconsistent with the very strong genotoxic effects detected in the comet assay, which were even higher than those of the positive control. However, while both assays detect single, as well as double strand breaks, only the alkaline comet assay is also able to detect so-called alkali labile sites (ALS). The term ALS summarizes a broad range of different modifications/lesions in the DNA (e.g., base alkylations, apurinic/apyrimidinic sites, intermediates of DNA damage repair) that will only result in strand breaks at very high $\mathrm{pH}$, thereby becoming detectable. Precisely at which pH ALS are converted into strand breaks depends on the type of ALS and varies according to literature in the range $\mathrm{pH}$ 12.6-13, increasing even above $\mathrm{pH} 13 .{ }^{46-48}$ In contrast to the alkaline comet assay, the $\mathrm{pH}$ used in the FADU assay (approximately 12.5-12.9) was probably insufficiently high to convert all kinds of ALS into strand breaks, explaining these differing results. For further confirmation, the neutral version of the comet assay was performed. Due to its low $\mathrm{pH}$ (approximately $\mathrm{pH}$ 10), primarily single, and some double strand breaks, but no ALS, can be detected. ${ }^{49}$ Indeed treatment with Au-NP I for $24 \mathrm{~h}$ resulted in approximately $15 \%-20 \%$ DNA damage in the neutral comet assay (Fig. 4e). This result is in agreement with the data obtained using the FADU assay. Therefore, we conclude that Au-NP I mainly induce alkali-labile sites and, to a lesser extent, also single or double strand breaks.

To distinguish between single and double strand breaks, we performed $\gamma \mathrm{H} 2 \mathrm{AX}$ immunofluorescence staining, a measure of DNA double strand breaks. Phosphorylation of histone H2AX and foci formation occur as an immediate response to the induction of DNA double strand breaks, to initiate DNA repair. The lack of such foci upon Au-NP treatment (Fig. 4f) indicates that the signals obtained in the neutral comet and FADU assays were primarily a result of single strand breaks. Collectively, our results strongly suggest that generation of ALS is the major source of genotoxicity in A549 cells following treatment with Au-NP I. Nevertheless, the question of whether 

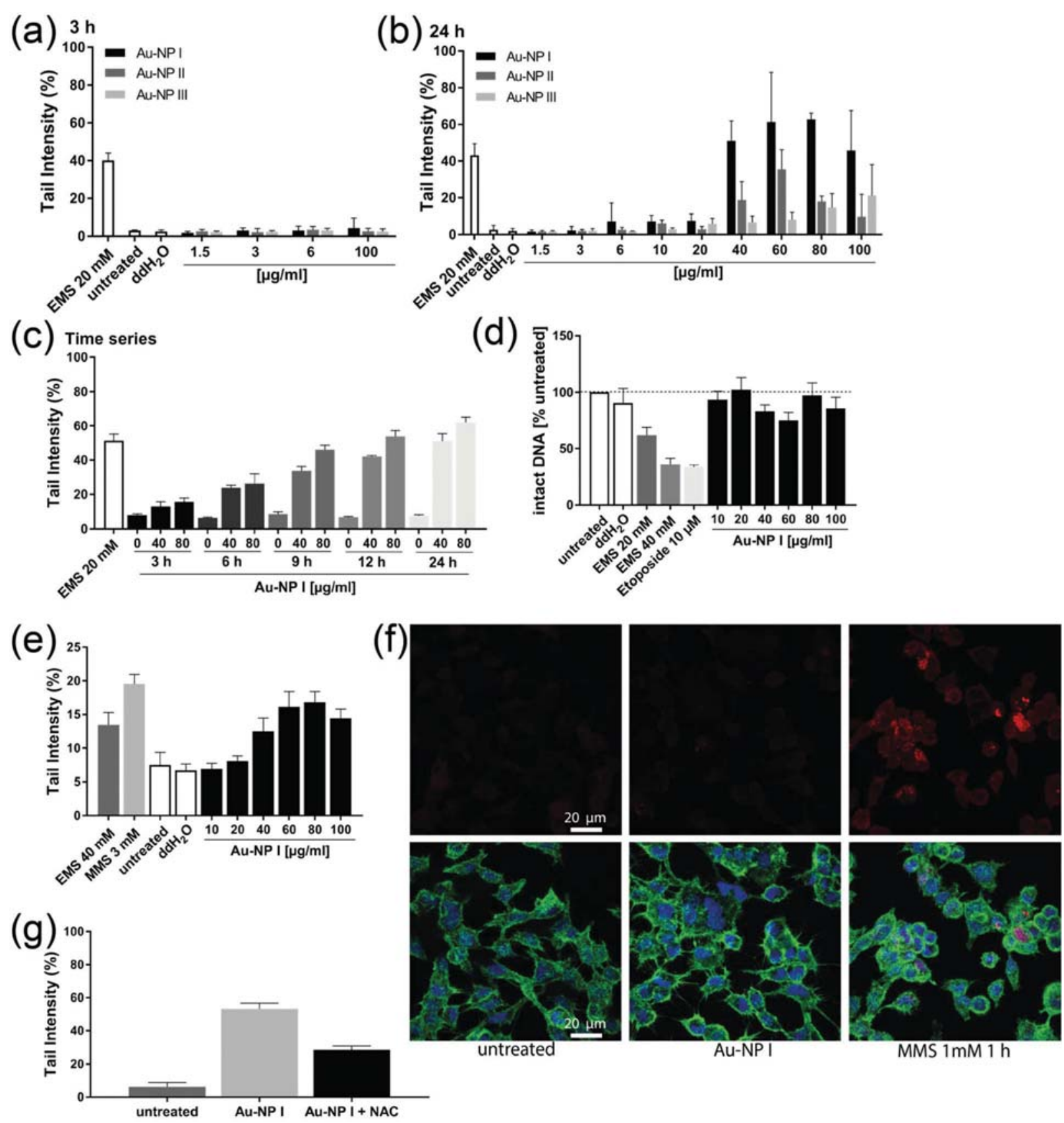

untreated

Au-NPI

MMS $1 \mathrm{mM} 1 \mathrm{~h}$

Fig. 4 Genotoxicity of Au-NPs. The potential of Au-NPs (I, II, and III) to cause DNA damage, expressed as \% tail intensity, was determined after (a) $3 \mathrm{~h}$ and (b) $24 \mathrm{~h}$ of exposure of A549 cells using the alkaline comet assay. (c) Time-dependent DNA damage induction was assessed after incubation with 40 and $80 \mu \mathrm{g} \mathrm{ml}^{-1} \mathrm{Au}-\mathrm{NP}$ I for 3, 6, 9, 12, and $24 \mathrm{~h}$. Ethyl methanesulfonate (EMS, $30 \mathrm{~min}$ ) served as the positive control in the alkaline comet assay. (d) DNA damage was detected by FADU assay, following $24 \mathrm{~h}$ of exposure to Au-NP I in A549 cells. Treatment with 20 and 40 mM EMS, or $10 \mu \mathrm{M}$ Etoposide, for $30 \mathrm{~min}$ served as positive controls. (e) The neutral comet assay was performed after $24 \mathrm{~h}$ of exposure of cells to Au-NP I. Treatment with EMS $(40 \mathrm{mM})$ and methyl methanesulfonate (MMS; $3 \mathrm{mM})$ for 30 min served as positive controls. Data shown represent the mean of three independent experiments and the corresponding standard deviation. (f) $\gamma \mathrm{H} 2 \mathrm{AX}$ foci, indicative of double strand break formation, were detected by immunofluorescence after $24 \mathrm{~h}$ exposure to $100 \mu \mathrm{g} \mathrm{ml}^{-1} \mathrm{Au}-\mathrm{NP}$ I. Treatment with $1 \mathrm{mM} \mathrm{MMS}$ for $1 \mathrm{~h}$ served as a positive control. Representative images of three independent experiments are shown. (g) DNA damage was detected by alkaline comet assay following co-exposure to $40 \mu \mathrm{g} \mathrm{ml}^{-1} \mathrm{Au}-\mathrm{NP}$ I and $\mathrm{N}$-acetylcysteine (NAC) for $24 \mathrm{~h}$. Data shown represent the mean of three independent experiments and the corresponding standard deviation.

the genotoxicity of Au-NPs is dependent on the observed induction of oxidative stress remains. To address this, the alkaline comet assay was performed using A549 cells co-exposed to
Au-NP I and $N$-acetylcysteine (NAC), a precursor of cellular GSH and important antioxidant, for $24 \mathrm{~h}$ (Fig. 4g). By elevating the level of NAC, Au-NP-induced DNA damage was significantly 
reduced, indicating that oxidative stress plays an important role in the genotoxicity of Au-NPs.

\section{Post-treatment observations and long-term effects}

The majority of publications on ENM-induced cyto- and genotoxicity have focused primarily on acute effects. In the past years, some studies have been performed on long-term effects of various cells mainly in regard to silver nanoparticles. ${ }^{50-52}$ Falagan-Lotsch et al. previously demonstrated the absence of cytotoxic effects of Au-NPs with varying shapes and surface coatings under long-term exposure. ${ }^{53}$ However, the rationale and the experimental setup of the long-term studies were quite diverse and most importantly did not include genotoxic Au-NPs.

After identification of quite massive DNA damage in A549 cells following exposure to Au-NP I and the absence of any detectable influence on cellular viability for up to $48 \mathrm{~h}$ (data not shown), the question arose whether the induced DNA damage by this single initial exposure had any influence on long-term viability of cells. Therefore, a long-term growth curve over a period of 14 days was performed to evaluate potential post-treatment effects (Fig. 5a). Initially, cells were seeded at a very low density (500 cells per well) and allowed to grow in the presence of Au-NP I. Treatment with different concentrations of NPs resulted in a minor lag in cell growth between days 6 and 8. Remarkably, by day 14, the difference in cell density was no longer detected, confirming that A549 cells remained intact, regardless of presence of DNA damage.

Damage to the genetic material is a constant threat to cells. To counteract DNA damage, and thereby maintain genomic integrity, several repair mechanisms, specific for various different types of lesion, have evolved (for a review see Dexheimer, 2013). ${ }^{34}$ One indication for DNA damage repair is cell cycle arrest, which often occurs as a cellular response to DNA damage. Activation of cell cycle checkpoints leads to a temporary arrest at a specific stage of the cell cycle, to allow the cell to repair defects. ${ }^{54,55}$ Therefore, following 24 and $48 \mathrm{~h}$ of exposure to $100 \mu \mathrm{g} \mathrm{ml}^{-1} \mathrm{Au}-\mathrm{NP}$ I, cell cycle analysis was performed using flow cytometry. While treatment with the DNA polymerase inhibitor, aphidicolin (APC; positive control) caused a distinct cell cycle pause in S-phase, Au-NP treatment had no significant influence on the cell cycle profile of A549 cells (Fig. 5b).

To assess DNA repair as a potential long-term effect, A549 cells were treated with Au-NP I at different concentrations, as
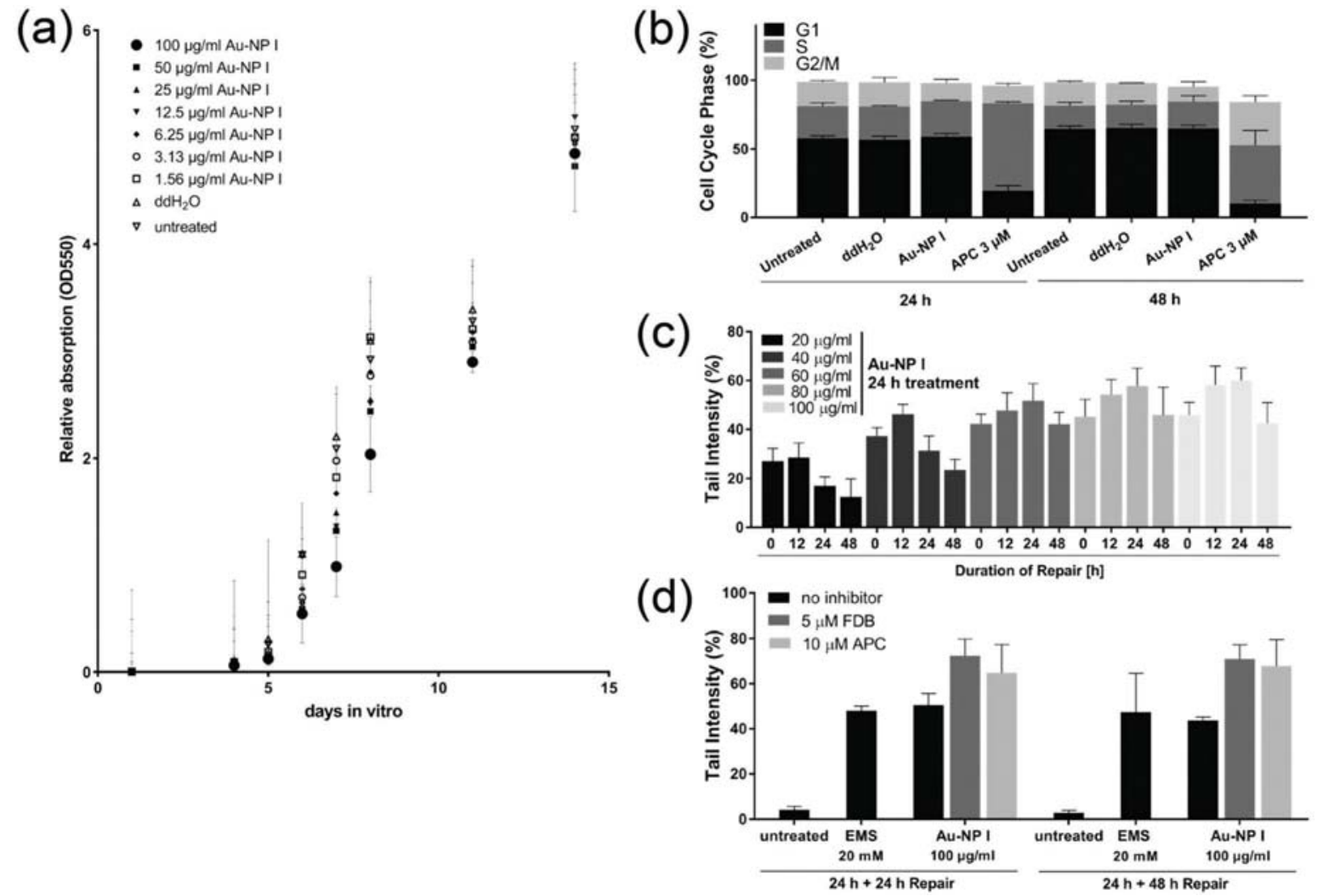

Fig. 5 Post-treatment effects and DNA repair. (a) Long-term growth curve of A549 cells treated with different concentrations of Au-NP I for 14 days assessed by crystal violet staining. (b) Flow cytometry cell cycle analysis of A549 cells after 24 and 48 h of Au-NP I treatment. Aphidicolin served as a positive control. (c) To assess DNA repair A549 cells were treated with Au-NP I for 24 h. Thereafter, cells were washed with PBS to remove remaining Au-NP. Cells were allowed to repair the induced DNA damage in fresh culture medium for 12, 24, and $48 \mathrm{~h}$. (d) DNA polymerases active in DNA repair were inhibited by aphidicolin (APC) and fludarabine (FDB) $2.5 \mathrm{~h}$ prior to cell harvest. DNA damage was assessed by alkaline comet assay. Treatment with $20 \mathrm{mM}$ EMS for $30 \mathrm{~min}$ served as a positive control. Data shown represent the mean of three independent experiments and the corresponding standard deviation. 
indicated in Fig. $5 \mathrm{c}$, for $24 \mathrm{~h}$. Thereafter, remaining Au-NPs in the supernatant were removed and cells allowed to repair the induced DNA damage in fresh culture medium for 12,24 , and $48 \mathrm{~h}$ (Fig. 5c). Detection of percentage tail intensities in the alkaline comet assay revealed an increase at the $12 \mathrm{~h}$ time point for the various concentrations used. After $24 \mathrm{~h}$, and particularly $48 \mathrm{~h}$, of "repair time", the DNA damage decreased, most notably in cells treated with the lower concentrations (20 and $40 \mu \mathrm{g} \mathrm{ml}^{-1}$ ) of Au-NP I.

For further clarification, the same experimental setup as that used for the DNA repair experiment was applied; however, in this experiment, cells were co-exposed to the DNA polymerase inhibitors APC $(10 \mu \mathrm{M})$ and fludarabine (FDB; $5 \mu \mathrm{M}), 2.5 \mathrm{~h}$ prior to cell harvesting after 24 and $48 \mathrm{~h}$ of repair time. Inhibition of DNA polymerases active in DNA repair by APC and FDB led to an increase in DNA damage. This result implies that inhibition of DNA repair processes reduced the observed decrease in DNA damage over time, indicating that the DNA repair mechanisms remain functional in the cells. Overall, our results demonstrate that cells are relatively tolerant to DNA damage induced by Au-NP in a single exposure scenario.

\section{Conclusions}

In summary, we demonstrate that Au-NPs are taken up by A549 cells without directly affecting cellular viability. Oxidative stress is observed; however, no inflammatory reactions are induced. Positively charged Au-NPs have the strongest capacity for DNA damage through induction of mainly alkali-labile sites. Importantly, we also demonstrate that despite massive induction of DNA damage after single exposure to Au-NP I, A549 cells could recover and repair damaged DNA over time. Our data highlight the importance of investigating NP-cell interactions, not only based on acute in vitro toxicity studies (e.g., according to the ROS paradigm), but with additional focus on potential long-term effects and DNA repair processes. Transient DNA damage effects may explain the discrepancy between the results from in vitro and in vivo genotoxic assessment of Au-NPs. To better understand the toxicological, and particularly the genotoxicological profiles of Au-NPs in vivo, studies focusing on particle clearance, genotoxicity, and DNA repair under conditions of long-term exposure are required.

\section{Experimental section}

\section{Cell culture}

A549 (ATCC: CCL-185) and THP-1 (ATCC: TIB-202) cells were obtained from the American Type Culture Collection. Both cell lines were routinely maintained under standard culture conditions (SCC) of $37{ }^{\circ} \mathrm{C}$ and $5 \% \mathrm{CO}_{2}$ in humidified atmosphere in RPMI-1640 (Sigma/Gibco) supplemented with 10\% Fetal Bovine Serum (Invitrogen), $2 \mathrm{mM}$ L-glutamine (Gibco), 50 $\mu \mathrm{g} \mathrm{mL}^{-1}$ penicillin, $50 \mu \mathrm{g} \mathrm{mL}^{-1}$ streptomycin $\mu \mathrm{g} \mathrm{mL}^{-1}$, and
$100 \mu \mathrm{g} \mathrm{mL}{ }^{-1}$ neomycin (Gibco). A549 cells were subcultured every 3-4 days at $80 \%-90 \%$ confluency using $0.5 \%$ Trypsin/ EDTA (Sigma). THP-1 cells were cultured in suspension, and cell concentrations were not allowed to exceed $1 \times 10^{6}$ cells per $\mathrm{ml}$. Differentiation into adhering macrophage-like cells was achieved by adding $200 \mathrm{nM}$ phorbol 12-myristate 13-acetate (PMA; Sigma) for three days prior to experiments.

\section{Lactate dehydrogenase (LDH) release assay}

A549 cells were seeded into 96-well plates at a density of $2 \times$ $10^{4}$ cells per well in a total volume of $100 \mu \mathrm{l}$ complete cell culture medium, $24 \mathrm{~h}$ prior to treatment. Cells were then treated for $24 \mathrm{~h}$ in $100 \mu \mathrm{l}$ of complete cell culture medium containing various concentrations of Au-NP (100, 50, 25, 12.5, $6.25,3.13,1.5$, or $0.78 \mu \mathrm{g} \mathrm{ml}^{-1}$ ) or remained untreated (complete cell culture medium only). Sodium dodecyl sulfate (SDS, $800 \mu \mathrm{M}$ ) served as the chemical positive control. LDH activity was detected in supernatants and cell lysates separately. Following treatment, supernatant aliquots $(20 \mu \mathrm{l})$ were used for measurement, and the remaining supernatants removed. Cells were lysed in PBS containing $0.1 \%$ Triton X-100 by pipetting up and down, followed by additional $2 \mathrm{~h}$ shaking at room temperature (RT). For the enzymatic reaction, $180 \mu \mathrm{l}$ of reaction buffer containing NADH $(616 \mu \mathrm{M})$ and sodium pyruvate $(240 \mu \mathrm{M})$ in KPP buffer was added to $20 \mu \mathrm{l}$ samples. KPP buffer was titrated to $\mathrm{pH} 7.4$, using approximately half the desired final volume of $9.7 \mathrm{mM} \mathrm{KH}_{2} \mathrm{PO}_{4}$ buffer and adding, while stirring, the appropriate amount of $40.24 \quad \mathrm{mM} \mathrm{K}_{2} \mathrm{HPO}_{4}$. Absorption was measured at $1 \mathrm{~min}$ intervals over $15 \mathrm{~min}$, using a multi-well plate reader $\left(\right.$ Mithras $^{2}$, Berthold Technologies) at $360 \mathrm{~nm}$ and $37^{\circ} \mathrm{C}$. Enzyme activity was calculated from the slope of the plotted data and the percentage of $\mathrm{LDH}$ release was calculated as $100 \times \mathrm{LDH}_{\text {supernatant }} /$

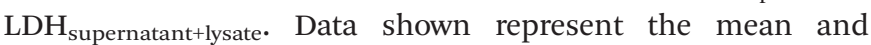
corresponding standard deviation of three independent experiments with three technical replicates each.

\section{Alkaline comet assay}

A549 cells were seeded into 6-well plates at a density of $2.5 \times$ $10^{5}$ cells per well in a total volume of $2.5 \mathrm{ml}$ complete cell culture medium $24 \mathrm{~h}$ prior to treatment. Thereafter, cells were incubated with several concentrations of Au-NP in $2.5 \mathrm{ml}$ of complete cell culture medium for 3 and $24 \mathrm{~h}$. Ethyl methanesulfonate (EMS; $20 \mathrm{mM}, 30 \mathrm{~min}$ ) served as the chemical positive control. Untreated samples were incubated in complete cell culture medium only. In some experiments, the polymerase inhibitors, aphidicolin (10 $\mu \mathrm{M}$; Sigma) and fludarabine ( $5 \mu \mathrm{M}$; Sigma), were added to cells $2.5 \mathrm{~h}$ prior to harvesting. Following treatment, cells were harvested with $0.2 \mathrm{ml} 0.5 \%$ Trypsin-EDTA and $0.3 \mathrm{ml}$ complete cell culture medium per well. Aliquots $(40 \mu \mathrm{l})$ of the resulting cell suspensions were mixed with $160 \mu \mathrm{l} 0.85 \%$ (w/v) low-melting point agarose (LMA) in PBS $\left(37^{\circ} \mathrm{C}\right)$. Aliquots $(70 \mu \mathrm{l})$ of these mixtures were applied to microscope slides, pre-coated with $1.5 \%(\mathrm{w} / \mathrm{v})$ agarose in PBS, overlaid with a coverslip, and LMA allowed to solidify for at least $10 \mathrm{~min}$ at $4{ }^{\circ} \mathrm{C}$. Then, coverslips were 
removed and cells lysed in lysis solution $(2.5 \mathrm{M} \mathrm{NaCl}, 100 \mathrm{mM}$ EDTA, $10 \mathrm{mM}$ Tris, 1\% (v/v) Na-Sarcosinate, 10\% (v/v) DMSO, $1 \%$ Triton-X-100; $\mathrm{pH} 10$ ) for $1 \mathrm{~h}$ at $4{ }^{\circ} \mathrm{C}$ in the dark. Slides were placed into a horizontal electrophoresis tray (PHERO-Comet 20-E, Biotec-Fischer) containing alkaline electrophoresis buffer (0.33 M NaOH, $1 \mathrm{mM}$ EDTA) for $20 \mathrm{~min}$ without current to allow DNA unwinding. Then electrophoresis was performed for $20 \mathrm{~min}$ at a constant voltage of $24 \mathrm{~V}$, resulting in a current of $300 \mathrm{~mA}$. Subsequently, samples were neutralized for $5 \mathrm{~min}$ in $0.4 \mathrm{M}$ TRIS ( $\mathrm{pH} 7.5$ ), rinsed in $\mathrm{ddH}_{2} \mathrm{O}$, dehydrated for $5 \mathrm{~min}$ in absolute ethanol, and air-dried overnight. DNA was stained with $20 \mu \mathrm{g} \mathrm{ml}^{-1}$ ethidium bromide and comets analyzed using a Nikon Eclipse TS 100 microscope (Nikon) equipped with an Intensilight C-HGFI lamp (Nikon) and a Stingray F046B IRF Jenofilt camera (Allied Vision Technologies). Quantification of head and tail regions was performed using "Comet Assay IV" software (Perceptive Instruments). Samples were blinded and 100 randomly chosen comets per sample were analyzed for each experiment. Tail intensities in percentages ( $=\%$ DNA in tail) are expressed as the mean and corresponding standard deviations of at least three independent experiments.

For experiments with more than one time point, cells were harvested as described and $0.5 \mathrm{ml}$ of cell suspension mixed with an equal volume of precooled freezing medium (50\% RPMI medium, 30\% FCS, $20 \%$ DMSO). Cells were then frozen at $-80{ }^{\circ} \mathrm{C}$ for at least $24 \mathrm{~h}$. For performance of the comet assay all samples from one experiment were thawed and centrifuged for $5 \mathrm{~min}$ at 200g. Pellets were resuspended in $0.5 \mathrm{ml}$ fresh media. Subsequently, the comet assay was performed as described above.

\section{Neutral comet assay}

All steps of the neutral comet assay were identical to those of the alkaline assay, up to electrophoresis; however, EMS (40 mM, $30 \mathrm{~min}$ ) and methyl methanesulfonate MMS (3 mM, $30 \mathrm{~min}$ ) served as chemical positive controls. Following lysis, slides were washed twice in precooled neutral electrophoresis buffer (0.3 M sodium acetate, $0.1 \mathrm{M}$ Tris- $\mathrm{HCl}$; $\mathrm{pH}$ 8.3), then placed into an electrophoresis tray (PHERO-Comet 20-E, Biotec-Fischer) containing the same electrophoresis buffer. Electrophoresis was performed for $40 \mathrm{~min}$ at 14 V. Subsequently, samples were washed twice for $5 \mathrm{~min}$ in PBS, rinsed in $\mathrm{ddH}_{2} \mathrm{O}$, dehydrated for $5 \mathrm{~min}$ in absolute ethanol, and air-dried overnight. Staining of DNA and subsequent analysis was performed as described above. Data shown represent the mean and corresponding standard deviation of at least three independent experiments.

\section{Fluorimetric analysis of alkaline DNA unwinding}

The gTOXXs system, based on the automated FADU assay described by Moreno-Villanueva et al., 2009 ${ }^{56,57}$ was used for detection of DNA strand breaks. Briefly, $24 \mathrm{~h}$ prior to experiments, $5 \times 10^{3}$, A549 cells were seeded into $\mu$ clear 96-well plates (Greiner) in $100 \mu \mathrm{l}$ complete cell culture medium and incubated under SCC. Thereafter, cells were treated with different concentrations $\left(100,80,60,40,20,10\right.$, or $\left.0 \mu \mathrm{g} \mathrm{ml}^{-1}\right)$ of Au-NP I in a total volume of $100 \mu \mathrm{l}$ complete cell culture media. EMS (20 or
$40 \mathrm{mM}$; $30 \mathrm{~min}$ ) served as positive control for strand break induction. Untreated samples were maintained in complete cell culture medium only. After 24 h, DNA strand break analysis was carried out using AUREA gTOXXs Analyzer (3T analytik; http:// www.aurea.solutions). Fluorescence measurements were performed using a multi-well plate reader (Mithras ${ }^{2}$, Berthold Technologies; excitation, $492 \mathrm{~nm}$; emission, $530 \mathrm{~nm}$ ). In the FADU assay, two different values are generated for each sample: one in which the DNA is not unwound, representing the total amount of double stranded DNA ( $T$-value); and one where the DNA is unwound by addition of an unwinding solution prior to neutralization solution ( $P$-value). Both $T$ - and $P$-values are used to assess nanoparticle-induced interference. To account for potential NP-derived influence (fluorescence quenching or enhancement) on the resulting $P$-values, each $P$-value is expressed as a percentage of its respective $T$-value. The overall fluorescence intensity of $P$-values is expressed as a percentage of that of control cells (i.e., cells not exposed to NP). A decrease in fluorescence intensity indicates an increase in DNA strand breaks. The mean of three technical replicates was calculated. Data shown represent the mean and corresponding standard deviation of four independent experiments.

\section{$\gamma \mathrm{H} 2 \mathrm{AX}$ foci}

$\gamma \mathrm{H} 2 \mathrm{AX}$ foci, which are indicative of double strand break formation, were detected by immunofluorescent staining. Briefly, A549 cells were seeded on coverslips $(12 \mathrm{~mm})$ in 24 -well plates at a density of $1.5 \times 10^{5}, 24 \mathrm{~h}$ prior to experimentation. Thereafter, cells were exposed to Au-NP I $\left(100 \mu \mathrm{g} \mathrm{ml} \mathrm{m}^{-1}\right)$ in complete cell culture medium (total volume, $0.5 \mathrm{ml}$ ); for solvent controls $\left(0 \mu \mathrm{g} \mathrm{ml}^{-1}\right)$ the equivalent volume of $\mathrm{ddH}_{2} \mathrm{O}$ was added, while untreated samples received complete cell culture medium only. Methyl methanesulfonate (MMS; $1 \mathrm{mM}, 1 \mathrm{~h}$ ) served as the chemical positive control. After $24 \mathrm{~h}$, cells were washed with PBS and fixed in $4 \%$ paraformaldehyde in PBS (20 min, RT), then blocked using 5\% goat serum in PBS for $1 \mathrm{~h}$, and subsequently incubated with mouse anti-phosphoHistone2AX (Ser139) antibody (clone JBW301; EMD Millipore, Catalog \#05-636) at a $1: 100$ dilution in PBS containing $0.5 \%$ BSA and $0.5 \%$ Tween-20 overnight at $4{ }^{\circ} \mathrm{C}$. Thereafter, cells were washed with PBS and incubated for $1 \mathrm{~h}$ with DAPI $\left(4^{\prime}, 6^{\prime}-\right.$ diamidino-2-phenylindole, $0.1 \mu \mathrm{g} \mathrm{ml}^{-1}$; Sigma), phalloidin 488 (1:100; Invitrogen) and the secondary antibody conjugated with Alexa Fluor $546(1: 400)$ in PBS containing $0.5 \%$ BSA. Coverslips were mounted on microscope slides using Mowiol 4-88 reagent (CALBIOCHEM) mounting medium. Images were obtained using a Zeiss Confocal microscope with a $63 \times$ objective lens. Images representative of four independent experiments are shown.

\section{Analysis of long-term cell growth}

To assess the long-term growth and viability of A549 cells, $5 \times$ $10^{2}$ cells per well were seeded into 96-well plates in a total volume of $100 \mu \mathrm{l}$ complete cell culture medium. One 96-well plate was used for each time point. After 24 h (day 1) A549 cells were exposed to the following concentrations of Au-NPs 
in complete cell culture medium: $100,50,25,12.5,6.25,3.13$, $1.5,0.78$, and $0 \mu \mathrm{g} \mathrm{ml}{ }^{-1}$. On day 4 , an additional $100 \mu \mathrm{l}$ of fresh complete cell culture medium without Au-NPs was added to the existing volume. On days $5,6,7,8,11$, and $14,100 \mu \mathrm{l}$ aliquots were carefully removed from wells and replaced with fresh medium without Au-NPs. Crystal violet staining was performed on days 1 (untreated), 4, 5, 6, 7, 8, 11, and 14 . Briefly, supernatants were carefully removed and cells were washed twice in $200 \mu \mathrm{l}$ pre-warmed PBS. PBS was removed and $100 \mu \mathrm{l}$ of $0.5 \%$ crystal violet in $20 \% \mathrm{MeOH}$ added per well. After incubation for 10 min at RT, cells were washed with tap water until no more dye was visible in the water. Cells were dried for $30 \mathrm{~min}$ at RT and finally, $100 \mu \mathrm{l} 100 \% \mathrm{MeOH}$ added to each well. Absorbance was measured at $550 \mathrm{~nm}$ in a multi-well plate reader (Mithras ${ }^{2}$, Berthold Technologies). Individual values were blank corrected and the mean of six technical replicates was calculated. Data shown represent the mean and corresponding standard deviation of three independent experiments.

\section{Nanoparticle uptake detection by flow cytometry}

A549 cells were seeded into 6-well plates at a density of $2.5 \times 10^{5}$ cells per well in a total volume of $2.5 \mathrm{ml}$ complete cell culture medium $24 \mathrm{~h}$ prior to treatment. These cells were treated for $24 \mathrm{~h}$ in $2.5 \mathrm{ml}$ of complete cell culture medium containing 100, 50 , or $10 \mu \mathrm{g} \mathrm{ml}^{-1} \mathrm{Au}-\mathrm{NP}$ or were untreated (complete cell culture medium only). Thereafter, cells were detached with $0.5 \%$ Trypsin-EDTA, pelleted by centrifugation $(200 \mathrm{~g}, 5 \mathrm{~min})$ and processed for flow cytometry. Changes in side scatter (SS) values were recorded on a logarithmic scale and plotted against linearly recorded forward scatter (FS) values or counts using a Gallios $^{\mathrm{TM}}$ flow cytometer and Kaluza software (Beckman Coulter). A total of 10000 counts were analyzed per sample. Data shown represent the mean and corresponding standard deviation of three independent experiments.

\section{Inductively coupled plasma optical emission spectroscopy}

A549 cells $\left(2.5 \times 10^{5}\right)$ were seeded in a total volume of $2.5 \mathrm{ml}$ complete cell culture medium per well in 6-well plates, $24 \mathrm{~h}$ prior to treatment. Thereafter, cells were treated for $24 \mathrm{~h}$ in $2.5 \mathrm{ml}$ of complete cell culture medium containing 100 $\mu \mathrm{g} \mathrm{ml} \mathrm{m}^{-1} \mathrm{Au}-\mathrm{NP}$ or remained untreated. For analysis, supernatants were collected, cells washed with PBS, trypsinized, and centrifuged (200g, $5 \mathrm{~min}$ ). After centrifugation the supernatant (trypsin fraction) and the wash fraction (PBS) were also collected and used for ICP-OES measurement. Cell pellets were resuspended in $200 \mu \mathrm{l}$ medium. Each sample was mixed with $50 \mu \mathrm{l}$ aqua regia and made up to a total volume of $4 \mathrm{ml}$ with $\mathrm{ddH}_{2} \mathrm{O}$ containing $2 \% \mathrm{HNO}_{3}$. Total Au content was measured using an Optima 300 inductively coupled plasma atomic emission spectrometer (PerkinElmer) with external calibration.

\section{Light microscopy}

A549 cells were seeded into 24 -well plates at a density of $1.5 \times$ $10^{5}$ cells per well in a total volume of $1 \mathrm{ml}$ complete cell culture medium. After $24 \mathrm{~h}$, cells were treated with 100 $\mu \mathrm{g} \mathrm{ml}^{-1}$ of the three different Au-NP preparations in a total volume of $0.5 \mathrm{ml}$ complete cell culture medium. After incubation for $24 \mathrm{~h}$ under SCC, images were obtained using a Zeiss Primovert microscope equipped with an Axiocam 105 color microscope camera (Carl Zeiss Microscopy, GmbH, Germany). Primo LD Plan-ACHROMAT 40×/0.05 Ph2 and 20×/0.03 PH1 objective lenses were used.

\section{Transmission electron microscopy}

A549 cells were seeded into 6-well plates at a density of $4 \times 10^{5}$ cells per well in a total volume of $2.5 \mathrm{ml}$ complete cell culture medium. After $24 \mathrm{~h}$, cells were treated with $100 \mu \mathrm{g} \mathrm{ml} \mathrm{g}^{-1}$ of AuNP in $2.5 \mathrm{ml}$ complete cell culture medium for $24 \mathrm{~h}$. Cells were detached from wells using 0.5\% Trypsin-EDTA, pelleted by centrifugation $(200 \mathrm{~g}, 5 \mathrm{~min})$ and drawn up into a capillary tube (Leica-Microsystems). Therein, cells were fixed in 3\% glutaraldehyde in $0.1 \mathrm{M}$ sodium cacodylate buffer. After a post-fixation step in $2 \%$ osmium tetroxide in $0.1 \mathrm{M}$ sodium cacodylate buffer, cells were dehydrated through a graded ethanol series, followed by acetone, and finally embedded in Epon resin (Sigma-Aldrich). Ultrathin sections were contrasted with $2 \%$ uranyl acetate and lead citrate ${ }^{58}$ before observation in a Zeiss EM 900 TEM (Carl Zeiss Microscopy, GmbH, Germany) at $80 \mathrm{kV}$.

\section{DCF assay}

Intracellular reactive oxygen species (ROS) were detected using $2^{\prime}, 7^{\prime}$-dichlorofluorescin diacetate $\left(\mathrm{H}_{2}\right.$ DCF-DA; Molecular Probes, Invitrogen), at $5 \mathrm{mM}$ in DMSO stock solution as reported previously with minor changes. ${ }^{33,59}$ Briefly, A549 cells were seeded at a density of $2 \times 10^{4}$ cells in $200 \mu$ l complete cell culture medium per well in 96-well plates $24 \mathrm{~h}$ prior to experiments. Thereafter, cells were loaded with $50 \mu \mathrm{M}$ $\mathrm{H}_{2}$ DCF-DA in Hank's balanced salt solution (HBSS) for $60 \mathrm{~min}$ under standard growth conditions. After two washing steps with pre-warmed HBSS, cells were treated with the following concentrations of Au-NP in HBSS: 100, 50, 25, 12.5, 6.25, 3.13, $1.5 \mu \mathrm{g} \mathrm{ml} l^{-1}, 0.75$, and $0 \mu \mathrm{g} \mathrm{ml}^{-1}$, with the $0 \mu \mathrm{g} \mathrm{ml} \mathrm{m}^{-1}$ sample receiving an equivalent volume of $\mathrm{ddH}_{2} \mathrm{O}$ in HBSS as a solvent control. Sin-1 (3-morpholinosydnonimine; $50 \mu \mathrm{M}$ ) served as the chemical positive control. Untreated samples received HBSS only. Fluorescence was measured in a multi-well plate reader (Mithras ${ }^{2}$, Berthold Technologies) after 1, 2, 3, and $4 \mathrm{~h}$. Cells were maintained under SCC between measurements. Fluorescence settings: excitation $\lambda=485 \mathrm{~nm}$, emission $\lambda=$ $528 \mathrm{~nm}$. Only values from the $3 \mathrm{~h}$ read point are presented in the results section. Individual values were blank corrected prior to further data processing. Data shown represent the mean and corresponding standard deviation of three independent experiments with three technical replicates each.

\section{Glutathione assay}

For measurement of oxidative stress, a Glutathione Assay Kit (Cayman Chemicals) was used according to the manufacturer's instructions to determine total GSH levels in A549 cells. Briefly, cells were seeded into 24-well plates at a density of 1.5 $\times 10^{5}$ cells per well in a total volume of $1 \mathrm{ml}$ complete cell culture medium. After $24 \mathrm{~h}$, cells were treated with 100 
$\mu \mathrm{g} \mathrm{ml}{ }^{-1}$ Au-NPs in a total volume of $0.5 \mathrm{ml}$ complete cell culture medium. The solvent control $\left(0 \mu \mathrm{g} \mathrm{ml} \mathrm{ml}^{-1}\right)$ received an equivalent volume of $\mathrm{ddH}_{2} \mathrm{O}$. Untreated samples were incubated in complete cell culture medium only. Buthionine sulfoximine (BSO, $125 \mu \mathrm{M}, 24 \mathrm{~h}$ ) served as the chemical positive control. Following treatment, supernatants were removed, cells washed with PBS, and collected in $0.3 \mathrm{ml}$ MES buffer. Cells were vortexed, sonicated in a sonication bath (Bandelin, Sonorex, Super RK $156 \mathrm{BH}$ ) for $3 \mathrm{~min}$, and centrifuged for $15 \mathrm{~min}$ at $10000 \mathrm{~g}$ at RT. Supernatants were collected and mixed with an equal volume of meta-phosphoric acid (MPA, Sigma), vortexed immediately, and incubated at RT for $5 \mathrm{~min}$. Subsequently, samples were centrifuged for $5 \mathrm{~min}$ at $2000 \mathrm{~g}$, and supernatants collected and frozen at $-20{ }^{\circ} \mathrm{C}$. When samples had been collected from all time points, they were thawed and $50 \mu \mathrm{l}$ of triethanolamine (TEAM, $4 \mathrm{M}$ ) added per $\mathrm{ml}$ of supernatant. Samples were then vortexed immediately and $50 \mu \mathrm{l}$ of each sample and the standard, transferred to 96-well plates in duplicates. The assay cocktail was freshly prepared, according to manufacturer's protocol, and $150 \mu \mathrm{l}$ applied to each well. Plates were covered with a sealing film and incubated in the dark on an orbital shaker for $25 \mathrm{~min}$, followed by measurement of absorbance (405 nm) in a multi-well plate reader (Mithras ${ }^{2}$, Berthold Technologies).

\section{Cytokine (TNF- $\alpha$ ) release detection by ELISA}

Detection of TNF- $\alpha$ was performed as previously described..$^{60}$ Briefly, THP-1 monocytes were seeded into 96-well plates at a density of $4 \times 10^{4}$ cells per well in a total volume of $200 \mu \mathrm{l} \mathrm{com-}$ plete cell culture medium containing $200 \mathrm{nM}$ PMA. After a differentiation period of $72 \mathrm{~h}$, PMA-containing medium was removed, cells washed twice with $200 \mu$ pre-warmed PBS, and treated with the following concentrations of Au-NP in $100 \mu \mathrm{l}$ complete cell culture medium (w/o PMA) for 8 and 24 h: 100, $50,25,12.5,6.25,3.13,1.5$, and $0 \mu \mathrm{g} \mathrm{ml}^{-1}$. LPS (10 and 100 $\mathrm{ng} \mathrm{ml}^{-1}$, from Salmonella enterica) served as the positive control. Untreated samples were maintained in complete cell culture medium. The pro-inflammatory cytokine, TNF- $\alpha$, was detected in cell culture supernatants (diluted $1: 10$ ) by sandwich-ELISA, according to the manufacturer's instructions (eBioscience). Data shown represent the mean and corresponding standard deviation of three independent experiments.

\section{Cell cycle analysis}

For cell cycle analysis A549 cells were seeded into 6-well plates at a density of $2.5 \times 10^{5}$ cells per well in a total volume of $2.5 \mathrm{ml}$ of complete cell culture medium. After $24 \mathrm{~h}$, cells were treated with $100 \mu \mathrm{g} \mathrm{ml}^{-1}$ Au-NPs in a total volume of $2.5 \mathrm{ml}$ complete cell culture medium for 24 and $48 \mathrm{~h}$; the solvent control $\left(0 \mu \mathrm{g} \mathrm{ml} \mathrm{m}^{-1}\right)$ received an equivalent volume of $\mathrm{ddH}_{2} \mathrm{O}$. Untreated samples received complete cell culture medium only. Aphidicolin (APC, 3 and $5 \mu \mathrm{M} ; 24$ and $48 \mathrm{~h}$ ) served as a positive control. For analysis, supernatants were removed, cells washed with PBS, and harvested with $0.2 \mathrm{ml} 0.5 \%$ TrypsinEDTA and $0.3 \mathrm{ml}$ complete cell culture medium per well. Cells were centrifuged $(200 \mathrm{~g}, 5 \mathrm{~min})$ and cell pellets resuspended in
$0.5 \mathrm{ml}$ PBS. EtOH $(70 \%, 4.5 \mathrm{ml})$ was added and samples vortexed for $10 \mathrm{~s}$, then incubated for $4 \mathrm{~h}$ at $4{ }^{\circ} \mathrm{C}$. Thereafter, cells were centrifuged $(300 \mathrm{~g}, 5 \mathrm{~min})$, washed with $1 \mathrm{ml} \mathrm{PBS}$, centrifuged $(300 \mathrm{~g}, 5 \mathrm{~min})$, and cell pellets resuspended in $1 \mathrm{ml}$ propidium iodide (PI) staining solution $\left(10 \mu \mathrm{g} \mathrm{m} \mathrm{m}^{-1} \mathrm{PI}\right.$, Sigma, $0.1 \%$ Triton $\mathrm{X}-100,0.1 \mathrm{mg} \mathrm{ml}^{-1}$ DNase free RNase A in PBS). Samples were incubated for $10 \mathrm{~min}$ at $37{ }^{\circ} \mathrm{C}$ and then analyzed using a Gallios ${ }^{\mathrm{TM}}$ flow cytometer and Kaluza software (Beckman Coulter). A total of 10000 counts were analyzed per sample. Data shown represent the mean and corresponding standard deviation of three independent experiments.

\section{Acknowledgements}

The authors acknowledge funding from the NanoScreen Materials Challenge co-funded by the Competence Centre for Materials Science and Technology (CCMX). We would like to thank Editage for English language editing.

\section{Notes and references}

1 E. E. Connor, J. Mwamuka, A. Gole, C. J. Murphy and M. D. Wyatt, Small, 2005, 1, 325-327.

2 C. M. Cobley, J. Y. Chen, E. C. Cho, L. V. Wang and Y. N. Xia, Chem. Soc. Rev., 2011, 40, 44-56.

3 H. Yasui, R. Takeuchi, M. Nagane, S. Meike, Y. Nakamura, T. Yamamori, Y. Ikenaka, Y. Kon, H. Murotani, M. Oishi, Y. Nagasaki and O. Inanami, Cancer Lett., 2014, 347, 151-158. 4 W. W. Li and X. Y. Chen, Nanomedicine, 2015, 10, 299-320.

5 K. Sokolov, M. Follen, J. Aaron, I. Pavlova, A. Malpica, R. Lotan and R. Richards-Kortum, Cancer Res., 2003, 63, 1999-2004.

6 J. Choi, J. Yang, D. Bang, J. Park, J. S. Suh, Y. M. Huh and S. Haam, Small, 2012, 8, 746-753.

7 M. Everts, V. Saini, J. L. Leddon, R. J. Kok, M. Stoff-Khalili, M. A. Preuss, C. L. Millican, G. Perkins, J. M. Brown, H. Bagaria, D. E. Nikles, D. T. Johnson, V. P. Zharov and D. T. Curiel, Nano Lett., 2006, 6, 587-591.

8 G. F. Paciotti, L. Myer, D. Weinreich, D. Goia, N. Pavel, R. E. McLaughlin and L. Tamarkin, Drug Delivery, 2004, 11, 169-183.

9 C. Tomuleasa, O. Soritau, A. Orza, M. Dudea, B. Petrushev, O. Mosteanu, S. Susman, A. Florea, E. Pall, M. Aldea, G. Kacso, V. Cristea, I. Berindan-Neagoe and A. Irimie, J. Gastrointestin. Liver Dis., 2012, 21, 187-196.

10 S. Her, D. A. Jaffray and C. Allen, Adv. Drug Delivery Rev., 2017, 109, 84-101.

11 S. Kang, S. Ahn, J. Lee, J. Y. Kim, M. Choi, V. Gujrati, H. Kim, J. Kim, E. C. Shin and S. Jon, J. Controlled Release, 2017, 256, 56-67. 
12 K. Niikura, T. Matsunaga, T. Suzuki, S. Kobayashi, H. Yamaguchi, Y. Orba, A. Kawaguchi, H. Hasegawa, K. Kajino, T. Ninomiya, K. Ijiro and H. Sawa, ACS Nano, 2013, 7, 3926-3938.

13 Y. Pan, S. Neuss, A. Leifert, M. Fischler, F. Wen, U. Simon, G. Schmid, W. Brandau and W. Jahnen-Dechent, Small, 2007, 3, 1941-1949.

14 J. Lebedová, Y. S. Hedberg, I. Odnevall Wallinder and H. L. Karlsson, Mutagenesis, 2018, 33, 77-85.

15 Q. Y. Xia, H. X. Li, Y. Liu, S. Y. Zhang, Q. Y. Feng and K. Xiao, J. Biomed. Mater. Res., Part A, 2017, 105, 710-719.

16 M. Tsoli, H. Kuhn, W. Brandau, H. Esche and G. Schmid, Small, 2005, 1, 841-844.

17 J. J. Li, L. Zou, D. Hartono, C. N. Ong, B. H. Bay and L. Y. L. Yung, Adv. Mater., 2008, 20, 138-142.

18 S. Di Bucchianico, M. R. Fabbrizi, S. Cirillo, C. Uboldi, D. Gilliland, E. Valsami-Jones and L. Migliore, Int. J. Nanomed., 2014, 9, 2191-2204.

19 M. C. Daniel and D. Astruc, Chem. Rev., 2004, 104, 293-346.

20 K. T. Butterworth, J. A. Coulter, S. Jain, J. Forker, S. J. McMahon, G. Schettino, K. M. Prise, F. J. Currell and D. G. Hirst, Nanotechnology, 2010, 21(29), 295101.

21 J. J. Li, S. L. Lo, C. T. Ng, R. L. Gurung, D. Hartono, M. P. Hande, C. N. Ong, B. H. Bay and L. Y. L. Yung, Biomaterials, 2011, 32, 5515-5523.

22 M. Schulz, L. Ma-Hock, S. Brill, V. Strauss, S. Treumann, S. Groters, B. van Ravenzwaay and R. Landsiedel, Mutat. Res., Genet. Toxicol. Environ. Mutagen., 2012, 745, 51-57.

23 N. J. Siddiqi, M. A. K. Abdelhalim, A. K. El-Ansary, A. S. Alhomida and W. Y. Ong, J. Neuroinflammation, 2012, 9, 123.

24 L. Gonzalez, D. Lison and M. Kirsch-Volders, Nanotoxicology, 2009, 3, 61-71.

25 R. De Bont and N. van Larebeke, Mutagenesis, 2004, 19, 169-185.

26 C. Buzea, I. I. Pacheco and K. Robbie, Biointerphases, 2007, 2, MR17-MR71.

27 G. Oberdorster, E. Oberdorster and J. Oberdorster, Environ. Health Perspect., 2005, 113, 823-839.

28 D. M. Brown, V. Stone, P. Findlay, W. MacNee and K. Donaldson, Occup. Environ. Med., 2000, 57, 685-691.

29 A. A. Shvedova, A. Pietroiusti, B. Fadeel and V. E. Kagan, Toxicol. Appl. Pharmacol., 2012, 261, 121-133.

30 I. M. Kennedy, D. Wilson, A. I. Barakat and H. E. I. H. R. Committee, Research report, 2009, pp. 3-32.

31 H. M. Lee, D. M. Shin, H. M. Song, J. M. Yuk, Z. W. Lee, S. H. Lee, S. M. Hwang, J. M. Kim, C. S. Lee and E. K. Jo, Toxicol. Appl. Pharmacol., 2009, 238, 160-169.

32 H. Sies, Am. J. Med., 1991, 91, S31-S38.

33 M. Roesslein, C. Hirsch, J. P. Kaiser, H. F. Krug and P. Wick, Int. J. Mol. Sci., 2013, 14, 24320-24337.

34 T. S. Dexheimer, in DNA Repair of Cancer Stem Cells, ed. L. A. Mathews, S. M. Cabarcas and E. M. Hurt, Springer Netherlands, Dordrecht, 2013, pp. 19-32, DOI: 10.1007/ 978-94-007-4590-2_2.

35 E. Frohlich, Int. J. Nanomed., 2012, 7, 5577-5591.
36 N. Bohmer, A. Rippl, S. May, A. Walter, M. B. Heo, M. Kwak, M. Roesslein, N. W. Song, P. Wick and C. Hirsch, Colloids Surf., B, under revision.

37 R. M. Zucker, E. J. Massaro, K. M. Sanders, L. L. Degn and W. K. Boyes, Cytometry, Part A, 2010, 77, 677-685.

38 N. Li, T. Xia and A. E. Nel, Free Radicals Biol. Med., 2008, 44, 1689-1699.

39 A. Nel, T. Xia, L. Madler and N. Li, Science, 2006, 311, 622627.

40 G. M. DeLoid, J. M. Cohen, G. Pyrgiotakis, S. V. Pirela, A. Pal, J. Liu, J. Srebric and P. Demokritou, Part. Fibre Toxicol., 2015, 12, 32.

41 S. Ritz, S. Schottler, N. Kotman, G. Baier, A. Musyanovych, J. Kuharev, K. Landfester, H. Schild, O. Jahn, S. Tenzer and V. Mailander, Biomacromolecules, 2015, 16, 1311-1321.

42 V. Escamilla-Rivera, M. Uribe-Ramirez, S. Gonzalez-Pozos, O. Lozano, S. Lucas and A. De Vizcaya-Ruiz, Toxicol. Lett., 2016, 240, 172-184.

43 A. Lesniak, F. Fenaroli, M. R. Monopoli, C. Aberg, K. A. Dawson and A. Salvati, ACS Nano, 2012, 6, 5845-5857.

44 J. H. Hoeijmakers, N. Engl. J. Med., 2009, 361, 1475-1485.

45 N. P. Singh, M. T. Mccoy, R. R. Tice and E. L. Schneider, Exp. Cell Res., 1988, 175, 184-191.

46 Vijayalaxmi, R. R. Tice and G. H. Strauss, Mutat. Res., 1992, 271, 243-252.

47 Y. Miyamae, K. Iwasaki, N. Kinae, S. Tsuda, M. Murakami, M. Tanaka and Y. F. Sasaki, Mutat. Res., 1997, 393, 107-113.

48 A. Eastman and M. A. Barry, Cancer Invest., 1992, 10, 229-240.

49 A. Azqueta and A. R. Collins, Arch. Toxicol., 2013, 87, 949968.

50 K. K. Comfort, L. K. Braydich-Stolle, E. I. Maurer and S. M. Hussain, ACS Nano, 2014, 8, 3260-3271.

51 T. Coccini, L. Manzo, V. Bellotti and U. De Simone, Sci. World J., 2014, 2014, 259765.

52 W. H. Choo, C. H. Park, S. E. Jung, B. Moon, H. Ahn, J. S. Ryu, K. S. Kim, Y. H. Lee, I. J. Yu and S. M. Oh, Toxicol. in Vitro, 2016, 37, 41-49.

53 P. Falagan-Lotsch, E. M. Grzincic and C. J. Murphy, Proc. Natl. Acad. Sci. U. S. A., 2016, 113, 13318-13323.

54 L. H. Hartwell and T. A. Weinert, Science, 1989, 246, 629-634.

55 L. H. Hartwell and M. B. Kastan, Science, 1994, 266, 18211828.

56 M. Moreno-Villanueva, R. Pfeiffer, T. Sindlinger, A. Leake, M. Muller, T. B. Kirkwood and A. Burkle, BMC Biotechnol., 2009, 9, 39.

57 M. Moreno-Villanueva, T. Eltze, D. Dressler, J. Bernhardt, C. Hirsch, P. Wick, G. von Scheven, K. Lex and A. Burkle, ALTEX, 2011, 28, 295-303.

58 E. S. Reynolds, J. Cell Biol., 1963, 17, 208-212.

59 A. Bachmatiuk, R. G. Mendes, C. Hirsch, C. Jahne, M. R. Lohe, J. Grothe, S. Kaskel, L. Fu, R. Klingeler, J. Eckert, P. Wick and M. H. Rummeli, ACS Nano, 2013, 7, 10552-10562.

60 C. Civardi, L. Schlagenhauf, J. P. Kaiser, C. Hirsch, C. Mucchino, A. Wichser, P. Wick and F. W. M. R. Schwarze, J. Nanobiotechnol., 2016, 14, 77. 